\title{
Response to NaCl Stress in Salix matsudana Koidz Seedlings
}

\author{
Binbin Li, Jie Ouyang, Chonghao Li, Xiaoshuo Shang, Jinhua Zou* \\ Tianjin Key Laboratory of Animal and Plant Resistance, College of Life Sciences, \\ Tianjin Normal University, Tianjin 300387, China
}

Received: 1 May 2017

Accepted: 11 July 2017

\begin{abstract}
The effects of different $\mathrm{NaCl}$ concentrations $(0.1,0.2$, and $0.4 \%$ ) on plant growth, the enzymatic antioxidant system, lipid peroxidation, and cell damage were investigated in Salix matsudana Koidz to better understand the tolerant mechanism under $\mathrm{NaCl}$ stress. The results indicate that cell damage was induced in roots by $\mathrm{NaCl}$ stress as early as after just $1 \mathrm{~h}$ of exposure, which increased with increasing $\mathrm{NaCl}$ concentration and prolonged treatment. The activities of SOD, POD, and CAT in S. matsudana under $\mathrm{NaCl}$ stress were enhanced except for the SOD activity in leaves under $0.4 \% \mathrm{NaCl}$ at day 28 , and CAT activities in leaves exposed to $0.4 \% \mathrm{NaCl}$ on days 21 and $28 . \mathrm{NaCl}$ exposure caused increasing $\mathrm{O}_{2}^{-}$and $\mathrm{H}_{2} \mathrm{O}_{2}$ contents. The MDA content in roots exposed to 0.2 and $0.4 \% \mathrm{NaCl}$ increased except for that in $0.2 \% \mathrm{NaCl}$ on day 14 compared with control. The MDA level in leaves of control was lower than that of all $\mathrm{NaCl}$ treatments. The soluble protein contents in roots increased significantly $(P<0.05)$, except for that $0.1 \% \mathrm{NaCl}$ during days 21 to 28 . It increased significantly in leaves exposed to $0.4 \% \mathrm{NaCl}$, but decreased sharply at day 28 .
\end{abstract}

Keywords: cell damage, enzymatic antioxidant system, lipid peroxidation, reactive oxygen species (ROS), soluble protein

\section{Introduction}

Soil salinity negatively affects agricultural and forestry productivity worldwide [1]. Increased salinization can affect arable land globally, and the loss of arable land is expected to be $30 \%$ in the next 25 years and in the year 2050 up to $50 \%$ [2]. It is well known that salinity can inhibit the growth and development of plants by excessive accumulation in plants [3].

Salt toxicity in plants has been known for a long time [4-5]. Apoptosis-like DNA degradation, which leads to

*e-mail: zjhmon@126.com sequential nuclear degradation, cell death and inhibition of root growth, has been observed after salt stress [6]. At the cellular level, salinity stress leads to an accumulation of reactive oxygen species (ROS) in the root and leaf tissues of plants [7-8]. Plants have evolved a range of complex physiological and metabolic responses to cope with adverse environments, including great stressresponsive genes and the synthesis of various functional proteins through a complex signal transduction network for alleviating the stress caused by salt [9-10]. Salinity can induce an antioxidant defense rising response to oxidative stress in plants. ROS, including superoxide anion $\left(\mathrm{O}_{2}^{-}\right)$, hydrogen peroxide $\left(\mathrm{H}_{2} \mathrm{O}_{2}\right)$, hydroxyl radical $\left(\mathrm{OH}^{\circ}\right)$, etc., are harmful byproducts of aerobic metabolism in aerobic 
organisms. Coordinated work of ROS-scavenging pathways from different cellular compartments may play a key role in plant salt tolerance by modulating the level of ROS in cells, preventing cellular damage and controlling ROS [11-12].

Plants have a range of antioxidant strategies to restrain these toxic compounds [13]. Under stress conditions, plants can maintain the safety level of ROS by altering the activity of many antioxidant enzymes and metabolites [14-15]. The activity levels of such antioxidant enzymes as superoxide dismutase (SOD), peroxidase (POD), catalase (CAT), and peroxidase (POX) are important for a plant's response to salinity stress [16-17]. These enzymes and metabolites not only protect plants from cellular damage, but also adjust ROS concentration to keep their functions better in the metabolism process [18]. In addition, many plants adapt to salt stress by enhanced biosynthesis of secondary metabolites, such as soluble solids, sugars, organic acids, proteins, and amino acids [19], which may act as osmolytes or osmoregulators to maintain plant turgor under salt stress.

S. matsudana (Chinese willow), a member of the Salicaceae family planted in northern China, mainly grows in the frigid and temperate regions of the northern hemisphere where low-rainfall and soil water retention, low temperature, and saline soil coexist [1]. As one of the most important landscaping and timber tree species, it has the good qualities of easy breeding, fast growth, resistance to water, and salt tolerance [20]. It was reported that $S$. matsudana could tolerate drought, salt, and heavy metal stress [1]. Salt toxicity in plants is well documented. However, limited information is available about the comprehensive evaluation of the toxic effects of salt on antioxidant enzymes, lipid peroxidation, and cell damage. Therefore, the aim of this work was to comprehensively evaluate the responses of the antioxidant system and the defense mechanisms in the seedlings of $S$. matsudana stressed by $\mathrm{NaCl}$ in order to better understand the tolerant mechanism in woody plants.

\section{Materials and Methods}

\section{Plant Material and Growth Conditions}

Healthy and equal-sized woody cuttings ( $25 \mathrm{~cm}$ long) from 1-year-old shoots of $S$. matsudana were collected before starting the experiments. After being dipped in tap water for $10 \mathrm{~d}$ at $25^{\circ} \mathrm{C}$, the plants were cultured with $1 / 2$ Hoagland nutrient solution for a week. Then the plants were randomly divided into four groups and treated with different concentrations of $\mathrm{NaCl}$ solution (control, 0.1, 0.2, and 0.4\%) for four weeks. The Hoagland nutrient solution consisted of $5 \mathrm{mM} \mathrm{Ca}\left(\mathrm{NO}_{3}\right)_{2}, 5 \mathrm{mM}$ $\mathrm{KNO}_{3}, 1 \mathrm{mM} \mathrm{KH} \mathrm{PO}_{4}, 1 \mathrm{mM} \mathrm{MgSO}{ }_{4}, 50 \mu \mathrm{M} \mathrm{H}_{3} \mathrm{BO}_{3}$, $10 \mu \mathrm{M}$ FeEDTA, $4.5 \mu \mathrm{M} \mathrm{MnCl}_{2}, 3.8 \mu \mathrm{M} \mathrm{ZnSO}_{4}, 0.3 \mu \mathrm{M}$ $\mathrm{CuSO}_{4}$, and $0.1 \mu \mathrm{M}\left(\mathrm{NH}_{4}\right)_{6} \mathrm{Mo}_{7} \mathrm{O}_{24}$, adjusted to $\mathrm{pH}$ 5.5. Control seedlings were grown in the nutrient solution alone. The solutions were constantly aerated with an air pump and replaced every week. Root and shoot length were measured every seven days. All treatments were done in three replicates.

\section{Propidium Iodide Staining}

To observe the cell damage in root tip cells of $S$. matsudana stressed by $\mathrm{NaCl}$, the intact root tips from the woody cuttings exposed to different concentrations of $\mathrm{NaCl}(0,0.1,0.2$, and $0.4 \%)$ for $1,3,6,9,12$, and $24 \mathrm{~h}$ were stained with propidium iodide (PI) in darkness at room temperature, and then they were washed three times $(3 \times 10 \mathrm{~min})$ with the sodium phosphate buffer (PBS) $(\mathrm{pH}$ 7.8), according to Koyama et al. [21] modified by Jones and Senft [22]. The fluorescence density was measured to analyze distribution in 10 intact root tips of $S$. matsudana woody cuttings under $\mathrm{NaCl}$ stress using the analysis and measure function of Image J software (NIH, Bethesda, MD, USA). The immunofluorescent specimens were examined with a confocal laser scanning microscope (ECLIPSE 90i, Nikon Corporation, Tokyo, Japan) with excitation maximum at $535 \mathrm{~nm}$ and fluorescence emission maximum at $617 \mathrm{~nm}$.

\section{Determining Antioxidant Enzyme Activities}

The fresh roots or leaves from each treatment were homogenized in a pestle and mortar with $0.05 \mathrm{M} \mathrm{PBS} \mathrm{(pH}$ 7.8 ) at the end of each time interval (7 d). The homogenate was centrifuged at $12,000 \times \mathrm{g}$ for $20 \mathrm{~min}$, and the supernatant was used for analyzing the activities of SOD, POD, and CAT. The above steps were carried out at $4^{\circ} \mathrm{C}$. More details are described by Wei et al. [23].

\section{Determining MDA Content}

The fresh roots and leaves $(0.15 \mathrm{~g})$ in each treatment were homogenized in $5 \mathrm{~mL}$ of $10 \%$ TCA (trichloroacetic acid) with a pestle and mortar at the end of each time interval $(7 \mathrm{~d})$. The homogenates were centrifuged at $12,000 \times \mathrm{g}$ for $15 \mathrm{~min} .2 \mathrm{~mL}$ of $0.6 \%$ thiobarbituric acid (TBA) in $10 \%$ TCA was added to $2 \mathrm{~mL}$ aliquot of the supernatant. The mixture was heated at $100^{\circ} \mathrm{C}$ for $15 \mathrm{~min}$ and then quickly cooled in an ice bath. The absorbance of the supernatant was recorded at 532 and $450 \mathrm{~nm}$. Lipid peroxidation was expressed as MDA content in $1 \mathrm{M} \mathrm{kg}^{-1}$ fresh weight.

\section{Determining Soluble Protein Concentration}

Measuring content of soluble proteins in this investigation was carried out according to Bradford's method [24] using bovine serum albumin (BSA) solution as a standard. The fresh roots and leaves from each treatment (six seedlings) were washed in distilled water, dried, and put in a mortar with $5 \mathrm{~mL} 0.05 \mathrm{M}$ PBS $(\mathrm{pH} 7.8)$ at the end of each time interval $(7 \mathrm{~d})$ of the $\mathrm{NaCl}$ treatment. The homogenate was centrifuged at $10,000 \times \mathrm{g}$ for $20 \mathrm{~min}$ and the supernatant was used for 
analyzing soluble protein contents. The soluble protein content was expressed as mg per $\mathrm{g}$ fresh weight.

\section{Determining $\mathrm{O}_{2}^{-}$and $\mathrm{H}_{2} \mathrm{O}_{2}$ Concentrations}

$\mathrm{H}_{2} \mathrm{O}_{2}$ content was determined based on Velikova [25]. Leaf and root fresh tissues $(0.5 \mathrm{~g})$ were homogenized by $5 \mathrm{~mL}$ of acetone into an ice bath at the end of each time interval $(7 \mathrm{~d})$. The mixture was centrifuged at $10,000 \times$ $\mathrm{g}$ for $20 \mathrm{~min}$ at $4^{\circ} \mathrm{C}$, and then $1 \mathrm{~mL}$ of the extract was mixed with $0.15 \mathrm{~mL}$ of $5 \%$ titanium sulfate and $0.2 \mathrm{~mL}$ of aqua ammonia. After precipitating, the mixture was centrifuged at $10,000 \times \mathrm{g}$ for $20 \mathrm{~min}$ at $4^{\circ} \mathrm{C}$. After the sediments were rinsed by acetone three times $5 \mathrm{~mL}$ of $2 \mathrm{M}$ sulphuric acid was added. Until sediments dissolved, the absorbance of the solution was recorded at $415 \mathrm{~nm}$ and $\mathrm{H}_{2} \mathrm{O}_{2}$ contents were measured using a standard curve.

$\mathrm{O}_{2}{ }_{2}^{-}$production rate was determined by monitoring the nitrite formation form hydroxyl-amine in the presence of $\mathrm{O}_{2}^{-}$according to Wang and Luo [26]. About $0.2 \mathrm{~g}$ frozen leaves were extracted with $2 \mathrm{~mL}$ of $50 \mathrm{mM}$ PBS

a)

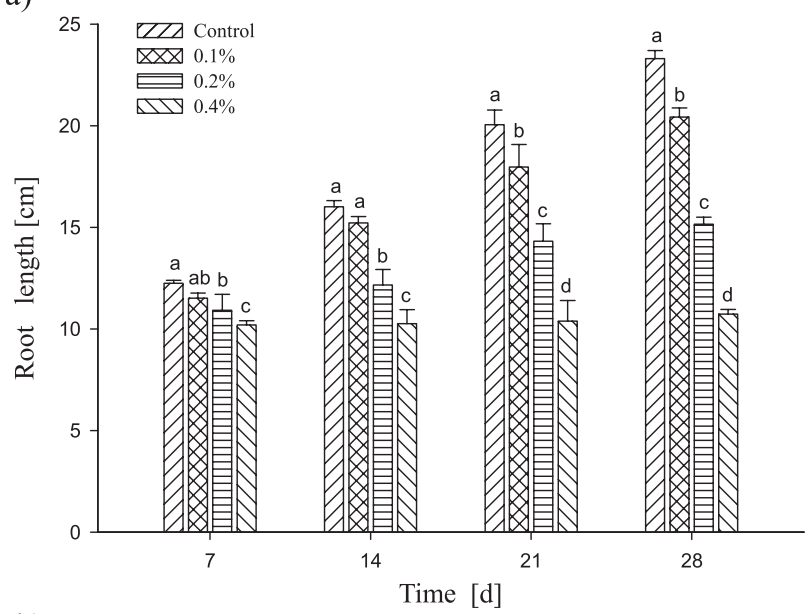

b)

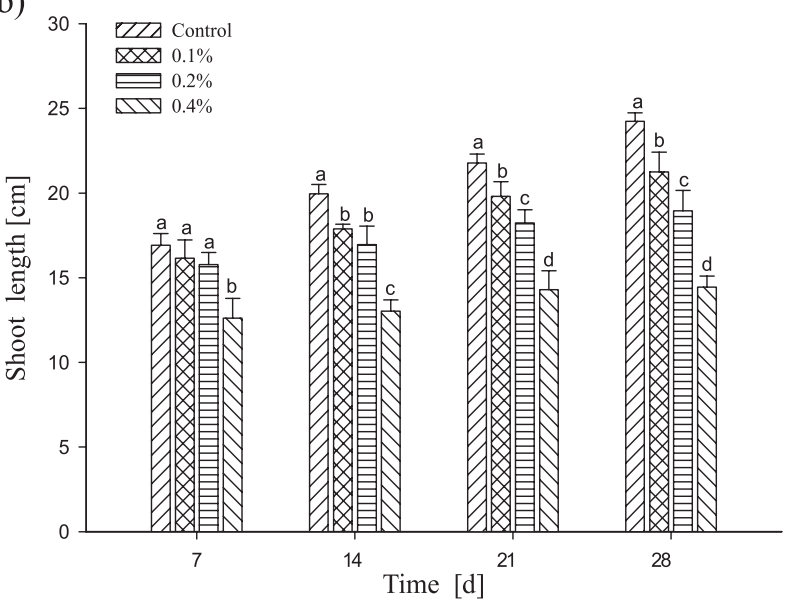

Fig. 1. Effects of different concentrations of $\mathrm{NaCl}(0.1,0.2$, and $0.4 \%)$ and treatment times $(7,14,21$, and 28 days) on root and shoot length of S. matsudana. Vertical bars denote SE. Values with different letters differ significantly from each other $(\mathrm{n}=10$, $P<0.05)$.
(pH 7.8) into an ice bath. The mixture was centrifuged at $12,000 \times \mathrm{g}$ for $20 \mathrm{~min}$ at $4^{\circ} \mathrm{C}$, and $0.5 \mathrm{~mL}$ supernatant was mixed with $0.5 \mathrm{~mL}$ of $50 \mathrm{mM}$ PBS ( $\mathrm{pH} 7.8$ ) and $1 \mathrm{~mL}$ of $1 \mathrm{mM}$ hydroxylamine hydrochloride. The mixture was incubated in a water bath for $20 \mathrm{~min}$ at $25^{\circ} \mathrm{C}$, and then $1 \mathrm{~mL}$ of $17 \mathrm{mM}$ sulfaniclic acid and $1 \mathrm{~mL}$ of $7 \mathrm{mM}$ 1-aminonaphthalene were added. The solution was then incubated for $20 \mathrm{~min}$ in a water bath at $25^{\circ} \mathrm{C}$, equal $4 \mathrm{~mL}$ volumes of chloroform were added, and the solution was centrifuged for $3 \mathrm{~min}$ at $12,000 \times \mathrm{g}$ at $25^{\circ} \mathrm{C}$. The absorbance of the supernatant was measured at
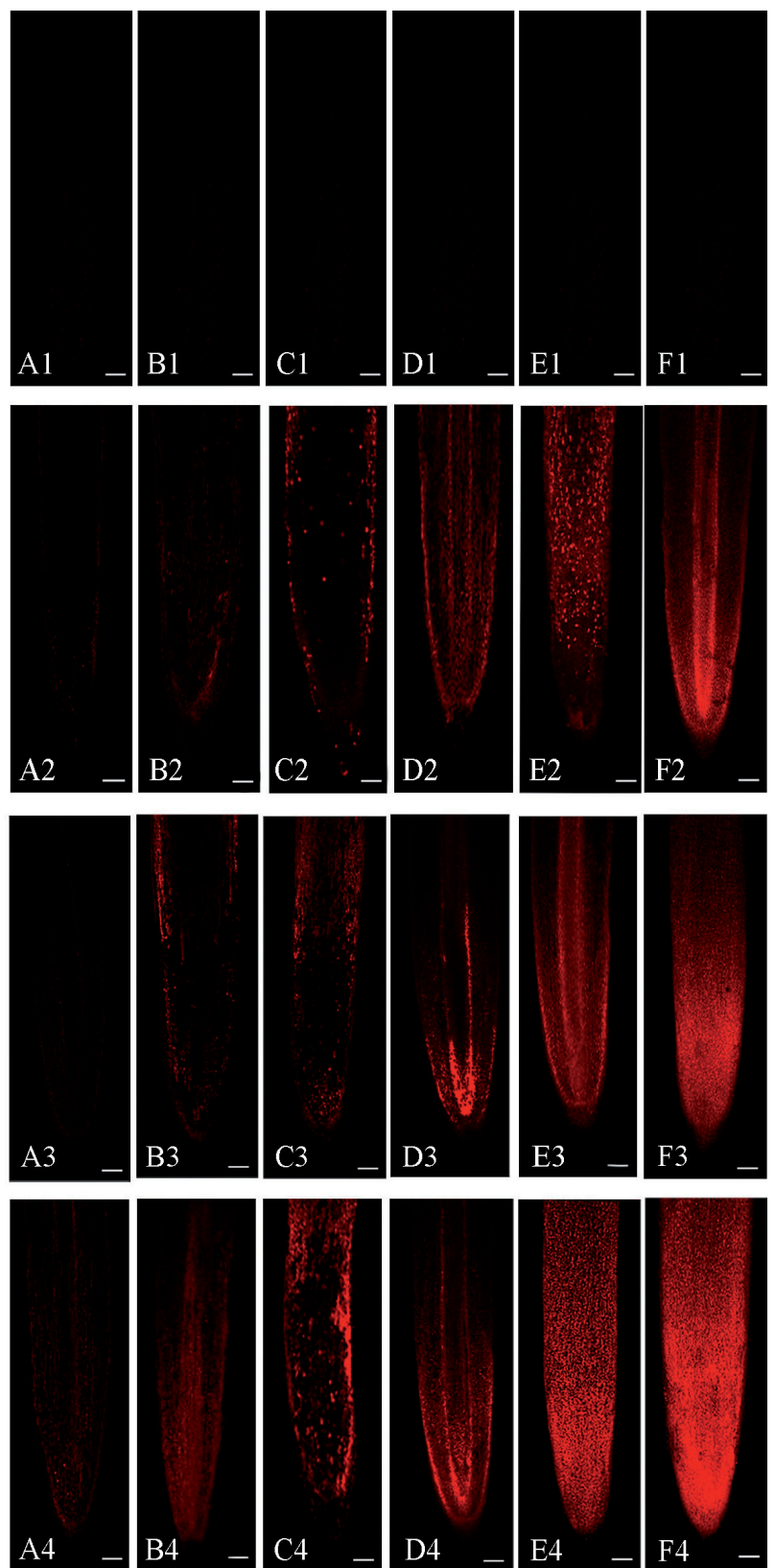

Fig. 2. Micrographs of roots from S. matsudana exposed to different $\mathrm{NaCl}$ concentrations using PI. Red fluorescence due to PI entering cells is an indicator of cell damage, A1-F1: control; A2-F2: $0.1 \% \mathrm{NaCl}$, for $1,3,6,9,12$, and $24 \mathrm{~h}$; A3-F3: $0.2 \%$ $\mathrm{NaCl}$, for 1, 3, 6, 9, 12, and $24 \mathrm{~h}$; A4-F4: $0.4 \% \mathrm{NaCl}$, for 1, 3, 6 , 9,12 , and $24 \mathrm{~h}$. Scale bar $=1 \mathrm{~mm}$. 


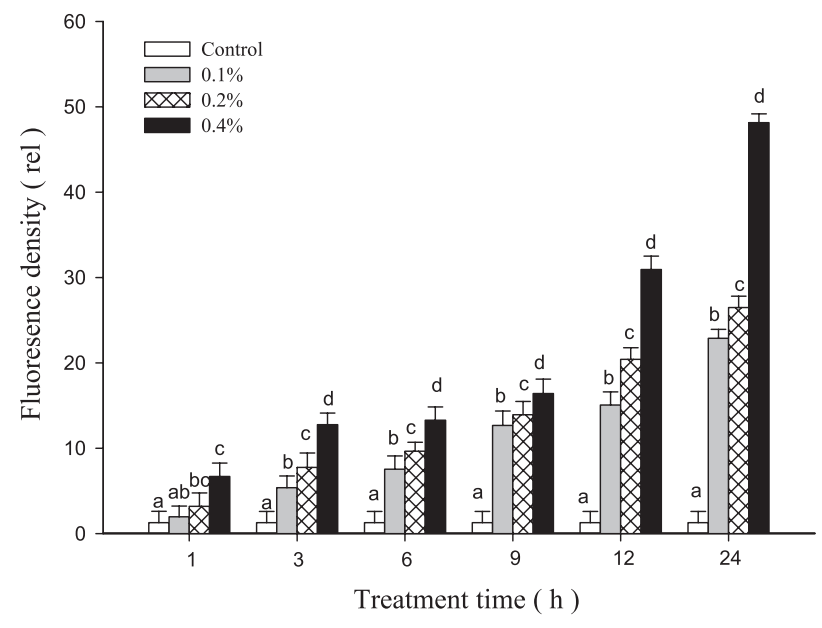

Fig. 3. Distribution of PI fluorescence density in roots of $S$. matsudana treated with $0,0.1,0.2$, and $0.4 \% \mathrm{NaCl}$ concentrations for different treatment times $(1,3,6,9,12$, and $24 \mathrm{~h})$. Values followed by the same letters are not significantly different $(P<0.05)$; means \pm standard error, $\mathrm{n}=15$.

$530 \mathrm{~nm}$ and the content of $\mathrm{O}_{2}^{-}$was calculated based on the standard curve.

\section{Statistical Analysis}

Each treatment was replicated five times for statistical validity. Analysis of variance of the data was done with SPSS and SigmaPlot 10.0 software. For statistical analysis, one-way analysis of variance (ANOVA) and $t$-test were used to determine the significance at $P<0.05$.

\section{Results}

\section{Effects of $\mathrm{NaCl}$ on Seedling Growth}

The effects of $\mathrm{NaCl}$ on the root and shoot growth of S. matsudana varied with the different concentrations and duration of treatment (Figs 1a-b). $\mathrm{NaCl}$ had no toxic effect on root growth at $0.1 \%$ concentration during days 7 and 14 of treatment when compared with control. With the increasing $\mathrm{NaCl}$ concentration and prolonged treatment time, root growth was inhibited significantly $(P<0.05)$. Under $0.4 \% \mathrm{NaCl}$, root growth almost completely stopped during the whole course of treatment (Fig. 1a). At $0.1 \%$ and $0.2 \%$ concentrations, the obvious inhibited effects in shoots appeared after $14 \mathrm{~d}$ treatment $(P<0.05)$ (Fig. 1b). The shoots exposed to $0.4 \% \mathrm{NaCl}$ showed significant reduction during the whole $\mathrm{NaCl}$ treatment period $(P<0.05)$ versus control and the other treatment groups.

\section{Effects of $\mathrm{NaCl}$ on Cell Damage}

To investigate the cell damage affected by $\mathrm{NaCl}$, the root tips of $S$. matsudana exposed to $0.1,0.2$, and $0.4 \%$ $\mathrm{NaCl}$ for $0,1,3,6,9,12$, and $24 \mathrm{~h}$ were stained with PI (Figs 2-3). Red fluorescence is an indicator of cell damage.
It is difficult to observe fluorescence in control root tips (Fig. 2A1-F1). The root tip cells of $S$. matsudana exposed to $0.1,0.2$, and $0.4 \% \mathrm{NaCl}$ for different periods of treatment exhibited different fluorescence intensities (Figs 2A2-F2, A3-F3, A4-F4). The low level of fluorescence intensity was observed in the root tips exposed to $\mathrm{NaCl}$ for $1 \mathrm{~h}$, showing that $\mathrm{NaCl}$ could induce cell damage as early as $1 \mathrm{~h}$. More and more red fluorescence appeared with increasing $\mathrm{NaCl}$ concentrations and prolonged exposure. The data from the fluorescence density analysis (Fig. 3) by software Image $J$ also confirmed the findings above (Fig. 2).

\section{Effects of $\mathrm{NaCl}$ on the Activities of SOD, POD, and CAT}

As shown in Figs 4(a-b), the effects of $\mathrm{NaCl}$ on SOD activities in roots and leaves of $S$. matsudana varied with different $\mathrm{NaCl}$ concentrations and duration of treatment time. The SOD activity in roots of $S$. matsudana exposed to $\mathrm{NaCl}$ during the 21-day period increased significantly $(P<0.05)$ versus control (Fig. 4a), and there was no obvious effect at day 28 in comparison with control. The SOD activity in leaves treated with $\mathrm{NaCl}$ increased significantly $(P<0.05)$ during the whole experiment except for the group exposed to $0.4 \% \mathrm{NaCl}$ at day 28 when compared with control (Fig. 4b). Higher SOD activities were observed in roots than in leaves in control and all the $\mathrm{NaCl}$ treatments. The POD activities in roots and leaves of $S$. matsudana are shown in Figs. 4(c-d). In comparison with control, significantly higher POD activity in roots and leaves was induced during the whole $\mathrm{NaCl}$ treatment time $(P<0.05)$ except for the leaves exposed to $0.1 \% \mathrm{NaCl}$ on days 7 and 14. Information on CAT activity in S. matsudana exposed to $\mathrm{NaCl}$ was given in Figs. 4(e-f). In roots, CAT activities increased significantly $(P<0.05)$ during the whole experiment except for the group exposed to $0.1 \%$ $\mathrm{NaCl}$ at day 28 (Fig. 4e). In comparison with control, the activities of CAT increased significantly $(P<0.05)$ in leaves exposed to 0.1 and $0.2 \% \mathrm{NaCl}$ during days 21 and 28. The CAT activity in leaves at concentrations of $0.4 \%$ $\mathrm{NaCl}$ increased significantly $(P<0.05)$ at days 7 and 14 of treatment when compared with control and the other treatment groups, then it decreased sharply at days 21 and 28 (Fig. 4f).

\section{Effects of $\mathrm{NaCl}$ on Lipid Peroxidation}

The effects of $\mathrm{NaCl}$ on MDA contents of $S$. matsudana are presented in Fig. 5. The content of MDA in roots exposed to $0.4 \% \mathrm{NaCl}$ was the highest during the whole experiment time except for the group treated with $0.4 \%$ $\mathrm{NaCl}$ on day 7 when compared with control and the other treatment groups (Fig. 5a). $0.2 \% \mathrm{NaCl}$ induced high levels of MDA in roots during the entire period of the experiment except for the treatment group at day 14. In leaves, the MDA contents increased significantly with increasing $\mathrm{NaCl}$ concentrations and prolonged treatment times (Fig. 5b). 


\section{Effects of $\mathrm{NaCl}$ on Soluble Protein Content}

As could be seen from Fig. 6a), the contents of soluble proteins in $S$. matsudana roots of all the $\mathrm{NaCl}$ treatments increased significantly $(P<0.05)$ during the whole experiment, except for the group exposed to $0.1 \% \mathrm{NaCl}$ at days 21 and 28 in comparison with control. Fig. 6b) showed that the soluble protein contents in leaves exposed to $0.4 \%$ $\mathrm{NaCl}$ increased significantly during the 21-day treatment $(P<0.05)$, except for the content in the group exposed to $0.2 \% \mathrm{NaCl}$ at day 7 when compared with control and the other treatment groups, but it decreased sharply at day
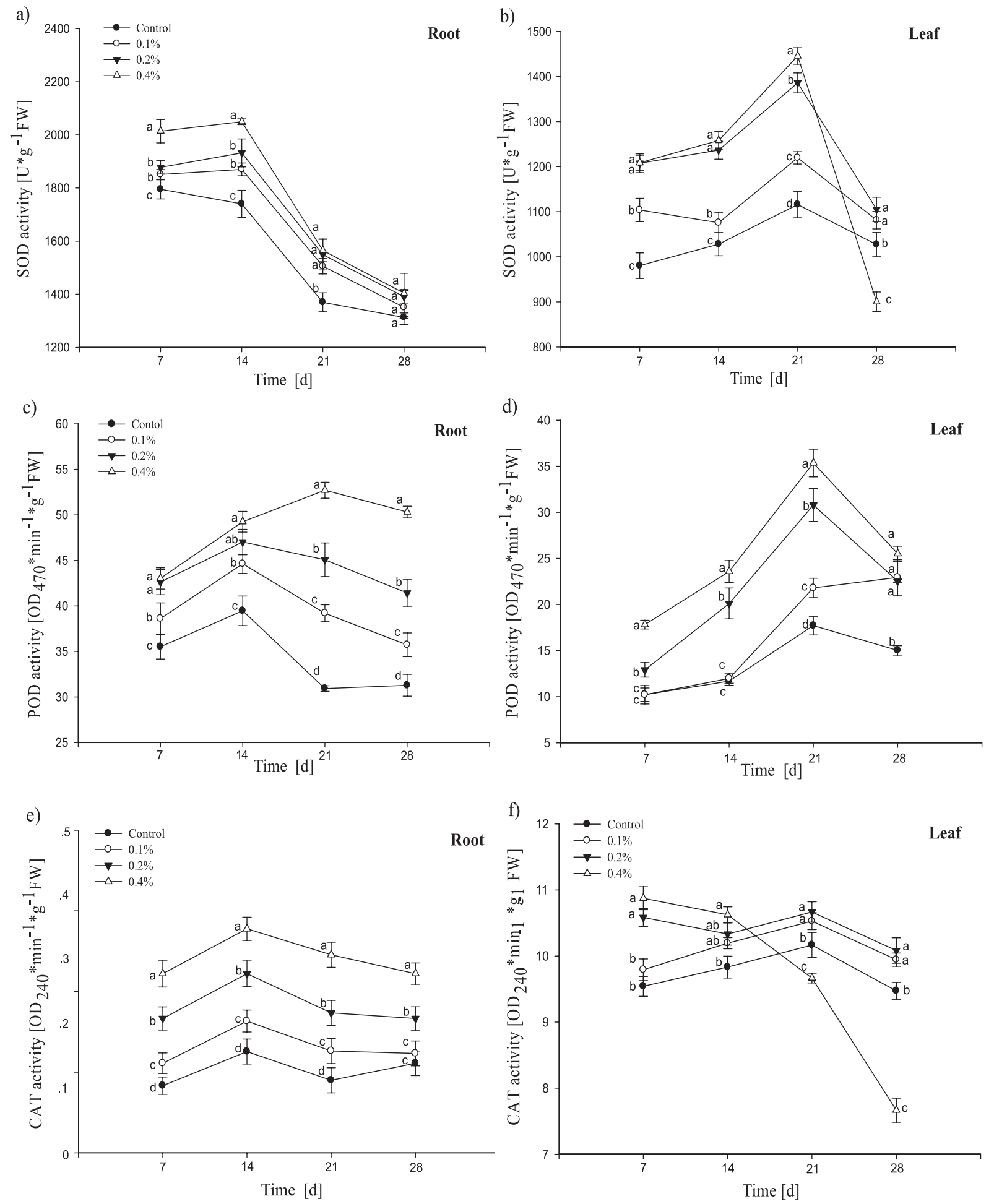

Fig. 4. Effects of different concentrations of $\mathrm{NaCl}$ on the activities of $\mathrm{SOD}, \mathrm{POD}$, and CAT in $S$. matsudana for 7, 14, 21 , and 28 days: a) SOD in roots, b) SOD in leaves, c) POD in roots, d) POD in leaves, e) CAT in roots, and f) CAT in leaves. Vertical bars denote SE. Values with different letters differ significantly from each other $(P<0.05, t$-test $)$. 
a)

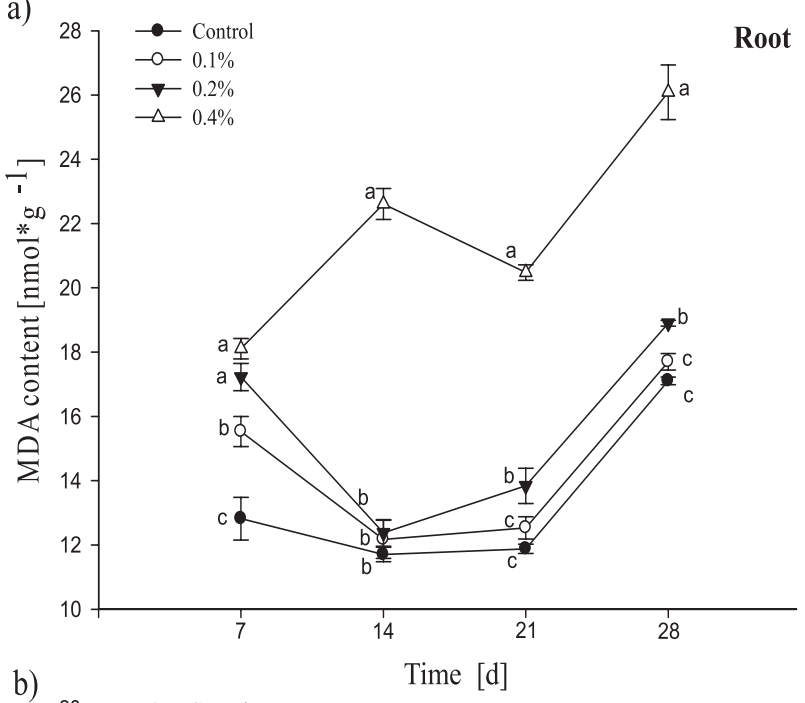

b)

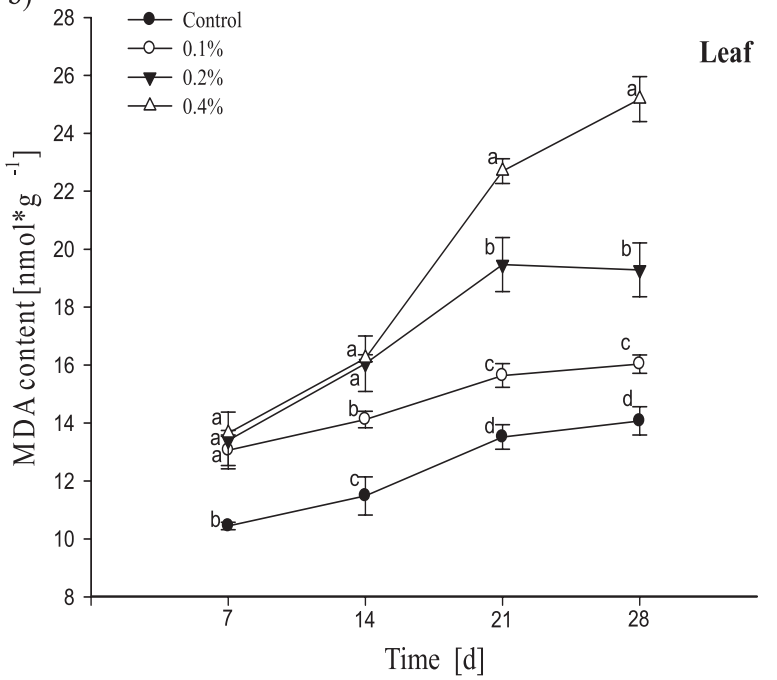

Fig. 5. Effects of different concentrations of $\mathrm{NaCl}$ on MDA content in S. matsudana for 7, 14, 21, and 28 days: a) roots and b) leaves. Vertical bars denote SE. Values with different letters differ significantly from each other $(P<0.05, t$-test $)$.

28 and was lower than the other groups. When compared with control, the soluble protein contents in the $0.1 \%$ and $0.2 \% \mathrm{NaCl}$ groups have no obvious difference during the 28-day treatment except those at day 7.

\section{Effects of $\mathrm{NaCl}$ on $\mathrm{O}_{2}^{-}$and $\mathrm{H}_{2} \mathrm{O}_{2}$ Content}

The effects of $\mathrm{NaCl}$ stress on $\mathrm{O}_{2}^{-}$and $\mathrm{H}_{2} \mathrm{O}_{2}$ content in $S$. matsudana are shown in Fig. 7. The $\mathrm{O}_{2}^{-}$contents in roots of all the $\mathrm{NaCl}$ treatment groups were raised significantly $(P<0.05)$ during the 14-28-day period when compared with control (Fig. 7a). The $\mathrm{O}_{2}{ }^{-}$contents reached the highest level at day 21 and then decreased sharply. The $\mathrm{O}_{2}^{-}$contents in leaves of all the $\mathrm{NaCl}$ treatments increased during the whole treatment time in comparison with the control, except for the $0.1 \% \mathrm{NaCl}$ group at day 28 (Fig. 7b). Effects of $\mathrm{NaCl}$ on $\mathrm{H}_{2} \mathrm{O}_{2}$ content in roots and leaves of $S$. matsudana varied with the different concentrations of $\mathrm{NaCl}$ and the duration of treatment.

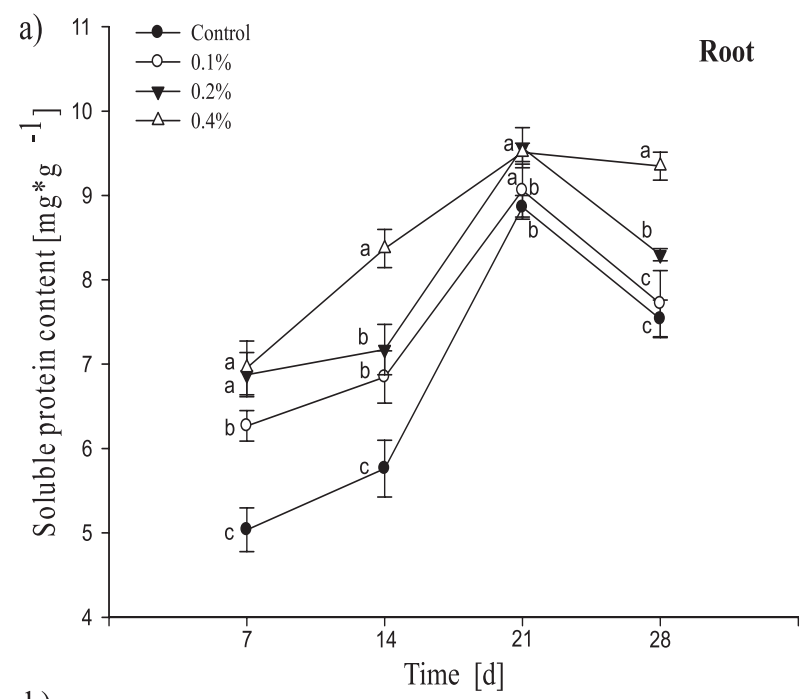

b)

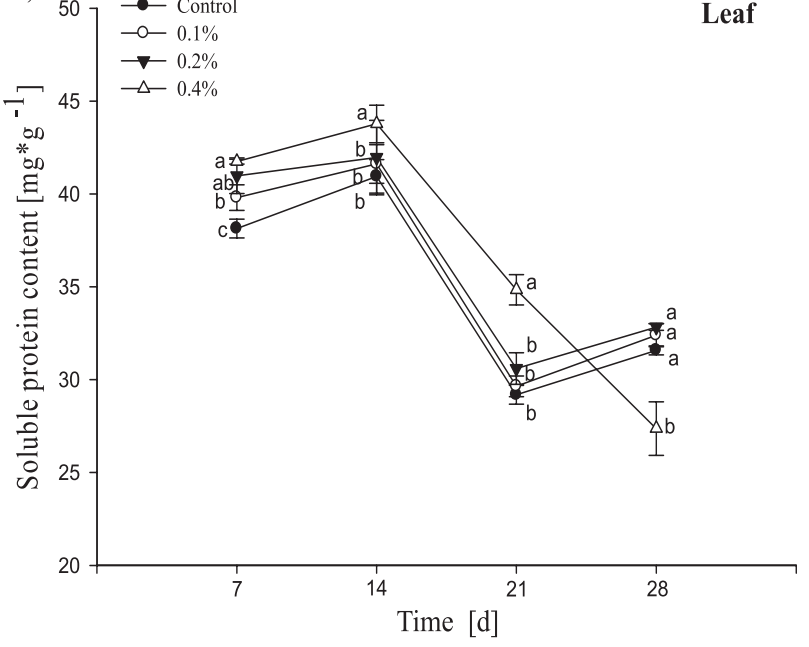

Fig. 6. Effects of different concentrations of $\mathrm{NaCl}$ on soluble protein content in $S$. matsudana for 7, 14, 21, and 28 days: a) roots and b) leaves. Vertical bars denote SE. Values with different letters differ significantly from each other $(P<0.05, t$-test $)$.

In roots, 0.2 and $0.4 \% \mathrm{NaCl}$ induced significantly high $\mathrm{H}_{2} \mathrm{O}_{2}$ content $(P<0.05)$ during the whole experiment when compared with control, except for $0.2 \% \mathrm{NaCl}$ at day 7 (Fig. 7c). The $\mathrm{H}_{2} \mathrm{O}_{2}$ content in leaves treated with $0.4 \%$ $\mathrm{NaCl}$ increased significantly $(P<0.05)$ during the whole treatment time when compared with control and the other treatment groups (Fig. 7d). The $\mathrm{H}_{2} \mathrm{O}_{2}$ contents in leaves exposed to 0.1 and $0.2 \% \mathrm{NaCl}$ increased significantly $(P<0.05)$ during the $21-28$-days period of treatment compared with control.

\section{Discussion}

Abiotic stresses such as high salinity, extreme temperature, drought, and heavy metal pollution are major limiting factors for growth and development of forest trees [27]. Salt stress negatively affects plant growth, morphology, and physiology as well as biochemical characteristics in plants [28-30]. The results from our 

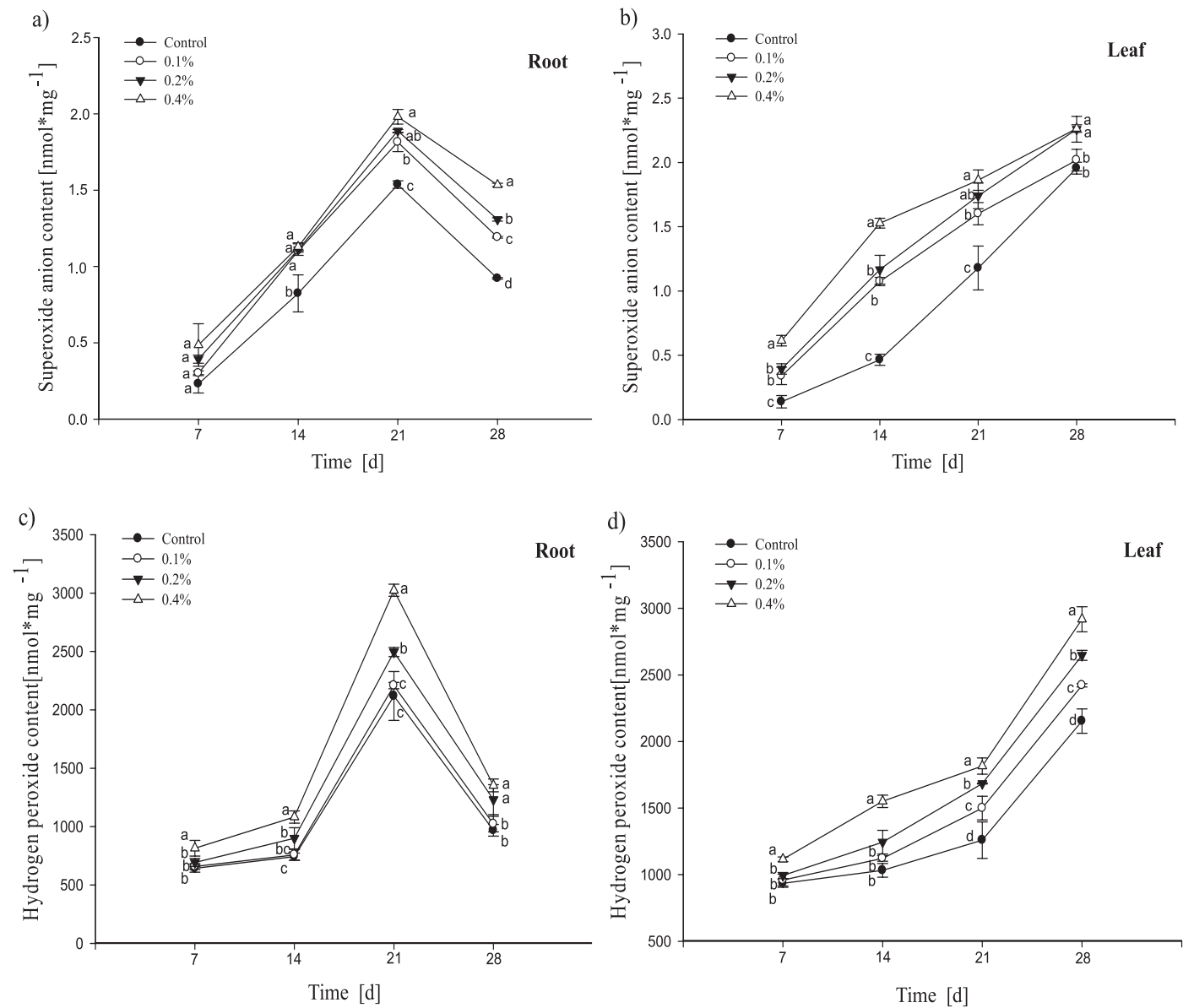

Fig. 7. Effects of different concentrations of $\mathrm{NaCl}$ on ROS content in S. matsudana for 7, 14, 21, and 28 days: a) $\mathrm{O}_{2}^{-}$content in roots, b) $\mathrm{O}_{2}^{-}$content leaves, c) $\mathrm{H}_{2} \mathrm{O}_{2}$ content in roots, and d) $\mathrm{H}_{2} \mathrm{O}_{2}$ content in leaves. Vertical bars denote SE. Values with different letters differ significantly from each other $(P<0.05, t$-test $)$.

physiological and biochemical investigation revealed several features in the seedlings of $S$. matsudana after short-term salt stress.

$0.4 \% \mathrm{NaCl}$ can inhibit seedling growth of $S$. matsudana severely, leading to near complete stoppage. Hence $0.4 \% \mathrm{NaCl}$ is the lethal concentration for seedling growth of $S$. matsudana under salt stress.

PI is an intercalating agent and a fluorescent molecule that can be used to stain DNA, which is an alternative agent to study cell membrane damage [31]. Morphological changes in the cells may be related to damage to the integrity of cell membranes [32]. Here, the toxic effect of $\mathrm{NaCl}$ stress on the cell membrane in the root tips of S. matsudana was confirmed by PI staining results. The lower level of fluorescence intensity was noted in the cells exposed to $\mathrm{NaCl}$ for $1 \mathrm{~h}$, showing that $\mathrm{NaCl}$ could induce cell damage as early as $1 \mathrm{~h}$. This toxic effect increased with increasing $\mathrm{NaCl}$ concentration and prolonged treatment time. Katsuhara [33] found that salt stress induced DNA degradation and cell death in barley root tips. When salt stress is temporary or adjustable at the seedling level, nucleotides could be produced by DNA degradation and relocated for shoots and new root formations. In this study, cell death was observed after salt stress. This cell death may lead to inhibition of root growth. A high concentration of $\mathrm{NaCl}$ can inhibit seedling growth of $S$. matsudana severely, leading to the growth almost being stopped completely.

Under salt stress, $\mathrm{ROS}$ such as $\mathrm{O}_{2}^{-}$, hydroxyl radicals $(-\mathrm{OH})$, and $\mathrm{H}_{2} \mathrm{O}_{2}$ are generally elevated [34]. ROS interfere with other cellular structures, resulting in oxidative damage like lipid peroxidation, protein, DNA damage, etc. [35]. The present investigation showed that $\mathrm{NaCl}$ exposure caused increasing $\mathrm{O}_{2}^{-}$and $\mathrm{H}_{2} \mathrm{O}_{2}$ contents of $S$. matsudana, associated with impaired integrity of the plasma membrane in S. matsudana. The plant plasma membrane is considered to be the first living structure affected by heavy metal and salt toxicity [36]. ROS can damage biomolecules and induce lipid peroxidation of the cell membranes [37]. Accordingly, the selectivity of cell membranes decreased due to damage to the cell membranes [38-39]. MDA formation is used as the general indicator of the extent of lipid peroxidation resulting from oxidative stress. The results in the present investigation showed that MDA content in the roots and leaves of $S$. matsudana under $\mathrm{NaCl}$ stress increased with increasing time, reflecting accumulating damage. Salinity can lead to oxidative stress, which is accompanied by the accumulation of lipid peroxidation products, including MDA. The results obtained here are consistent with earlier 
findings [1]. The results here showed that $\mathrm{NaCl}$ induced oxidative stress in both roots and leaves of $S$. matsudana as indicated by the increase of MDA, and $\mathrm{O}_{2}^{-}$and $\mathrm{H}_{2} \mathrm{O}_{2}$ levels. By analyzing the tendency of $\mathrm{H}_{2} \mathrm{O}_{2}$ and $\mathrm{O}_{2}^{-}$, we found that the contents of $\mathrm{H}_{2} \mathrm{O}_{2}$ and $\mathrm{O}_{2}{ }^{-}$rose first and then fell in the root, but they always increase in leaves. The roots are the first sensitive plant organ to make contact with the stresses and pollutants [39]. Hence, physiological and metabolic disorders and toxic symptoms appeared in the roots at first.

Plants have effective scavenging mechanisms to respond to damage [39]. The antioxidative enzymatic system plays a protective role by stabilizing the amounts of ROS in plant cells [40-41]. SOD is a cell's first line of defense against ROS as the superoxide radical, which is a precursor to several other highly reactive species, so that controlling the steady state of superoxide concentration by SOD constitutes an important protective mechanism [42]. POD activity reflects the modified mechanical properties of the cell wall and cell membrane integrity of plant leaves under stress conditions [43]. CAT is the most universal oxidoreductase, which scavenges $\mathrm{H}_{2} \mathrm{O}_{2}$ to $\mathrm{O}_{2}$ and $\mathrm{H}_{2} \mathrm{O}$. An adapted ROS scavenging system, including SOD, POD, CAT, ascorbate peroxidase (APX), and glutathione reductase (GR), could provide some protection against oxidative damage under salt-stressed conditions [44]. In the present investigation, the activity of SOD, CAT, and POD in roots and leaves of $S$. matsudana under $\mathrm{NaCl}$ stress was enhanced except for the SOD activity in leaves exposed to $0.4 \% \mathrm{NaCl}$ on day 28 , and CAT activities in leaves exposed to $0.4 \% \mathrm{NaCl}$ on days 21 and 28 , indicating their active involvement in scavenging ROS generated by $\mathrm{NaCl}$ toxicity, and suggesting that the plants have a high ability to tolerate salt stress due to an efficient antioxidant system. The effects of $\mathrm{NaCl}$ on SOD and POD were greater in roots than in leaves, explained by the fact that $\mathrm{NaCl}$ is in direct contact with the roots and is taken up mostly through roots. Of most high-concentration $\mathrm{NaCl}$ accumulated in roots, only small amounts penetrate the leaves. Thus roots suffer from more oxidative stress than the leaves. The decline in CAT activity in leaves at high $\mathrm{NaCl}$ concentration $(0.4 \%)$ is supposedly due to inhibition of enzyme synthesis or a change in assembly of enzyme. Possibly CAT is more sensitive to high concentrations of $\mathrm{NaCl}$ stress than SOD and POD.

Under $\mathrm{NaCl}$ stress, soluble protein contents in roots of $S$. matsudana increased significantly $(P<0.05)$, except for the groups exposed to $0.1 \% \mathrm{NaCl}$ during days 21 to 28 . The high-soluble protein content induced by $\mathrm{NaCl}$ may be explained by the following aspect. Salt induces a high expression of multiple genes and increases the synthesis of several primitive proteins. The results in the present investigation showed that soluble protein contents of $S$. matsudana subjected to salt stress were greater than those of plants under non-saline conditions. Soluble protein contents in leaves were greater than those in roots. High salinity levels induce osmotic stress, which is an important mechanism for plants to tolerate salt stress [4546]. It is an important mechanism through increased net concentrations of solutes or osmotic adjustment to lower cell water potential for maintaining cell water content [47]. Decreasing the osmotic potential of the cell and stabilizing membranes and macro-molecular structure are two possible physiological responses dealing with the accumulation of osmolyte under stress [48].

\section{Conclusions}

Plants have evolved complex mechanisms for minimizing the damage from exposure to non-essential high $\mathrm{NaCl}$. Once $\mathrm{NaCl}$ concentration in the cell is too high, a defence mechanism is activated, protecting the cells against oxidative stress, which may result in cell death and stress-induced adaptation and survival.

In view of the present investigation, with increasing $\mathrm{NaCl}$ concentration, the number of broken and dead cells was obviously increasing. Root growth was seriously inhibited, which might be mainly caused by the death of massive root cells under high concentration and long treatment time. With increased $\mathrm{NaCl}$ concentration, ROS showed a significant increasing trend. Meanwhile, with the excess ROS aggravating, the plant cell membrane system was hurt, which leads to the content of MDA and osmotic regulation substances being changed. The alterations of antioxidant enzymes, lipid peroxidation, and cell damage changes in $S$. matsudana can serve as useful biomarkers to estimate the extent of damage a plant suffered with $\mathrm{NaCl}$. Data obtained here may be important for understanding the tolerant mechanism under $\mathrm{NaCl}$ stress in woody plants.

\section{Acknowledgements}

This project was supported by the Natural Science Foundation of Tianjin, China. The authors wish to express their appreciation to the reviewers for their comments and suggestions.

\section{References}

1. QIAO G.R., ZHANG X.G., JIANG J., LIU M.Y., HAN X.J., YANG H.Q., ZHUO R.Y. Comparative proteomic analysis of responses to salt stress in Chinese Willow (Salix matsudana Koidz). Plant Mol. Biol. Rep. 32, 814, 2014.

2. WANG W.X., VINOCUR B., ALTMAN A. Plant responses to drought, salinity and extreme temperatures: towards genetic engineering for stress tolerance. Planta 218, 1, 2003.

3. CARVALHO M.F., CORREA M.M., CARVALHO G.C., ROLIM NETO F.C., MARINHO G.P.A., ANDRADE S.B.D. Enzymatic activity of three sugarcane varieties under salt stress. Rev. Bras. Eng. Agr. Amb. 20, 806, 2016.

4. VUJAKOVIC M., BALEŠEVIĆ-TUBIĆ S., JOVIČIĆ D., TAŠKI-AJDUKOVIĆ K., PETROVIĆ D., NIKOLIĆ Z., ĐORĐEVIĆ V. Viability of soybean seed produced under different agro-meteorological conditions in Vojvodina. Genetika 43, 625, 2011. 
5. ACOSTA-MOTOS J.R., ORTUÑO M.F., BERNALVICENTE A., DIAZ-VIVANCOS P., SANCHEZBLANCO M.J., HERNANDEZ J.A. Plant responses to salt stress: adaptive mechanisms. Agron. 7, 18, 2017.

6. KATSUHAR M., KAWASAKI T. Salt stress induced nuclear and DNA degradation in meristematic cells of barley roots. Plant Cell Physiol. 37, 169, 1996.

7. HERNANDEZ M., FERNANDEZ-GARCIA N., DIAZVIVANCOS P., OLMOS E. A different role for hydrogen peroxide and the antioxidative system under short and long salt stress in Brassica oleracea roots. J. Exp. Bot. 61, 521, 2010.

8. CHOUDHURY S., PANDA P., SAHOO L., PANDA S.K. Reactive oxygen species signaling in plants under abiotic stress. Plant Signal. Behav. 8, e23681, 2013.

9. MAHAJAN S., TUTEJA N. Cold, salinity and drought stresses: An overview. Arch. Biochem. Biophys. 444, 139, 2005.

10. YOU J., CHAN Z.L. ROS regulation during abiotic stress responses in crop plants. Front. Plant Sci. 6, 1092, 2015.

11. MILLER G., SUZUKI N., CIFTCI-YILMAZ S., MITTLER R. Reactive oxygen species homeostasis and signalling during drought and salinity stresses. Plant, Cell Environ. 33, 453, 2010.

12. PANG C.H., WANG B.S. Oxidative Stress and Salt Tolerance in Plants. Prog. Bot. 69, 231, 2008.

13. LAUER N., ROSS C. Physiological and oxidative stress responses of baldcypress in response to elevated salinity: linking and identifying biomarkers of stress in a keystone species. Acta. Physiol. Plant 38, 275, 2016.

14. MITTLER R., VANDERAUWERA S., GOLLERY M., BREUSEGEM F.V. Reactive oxygen gene network of plants. Trends Plant Sci. 9, 490, 2004.

15. ABOGADALLAH G.M. Antioxidative defense under salt stress. Plant Signal. Behav. 5, 369, 2010.

16. ASHRAF M., AKRAM N.A. Improving salinity tolerance of plants through conventional breeding and genetic engineering: an analytical comparison. Biotechnol. Adv. 27, 26, 2009.

17. MITTOVA V., VOLOKITA M., GUY M. Antioxidative systems and stress tolerance: Insight from wild and cultivated tomato species. Springer International Publishing, Switzerland, 23, 89, 2015.

18. BECANA M., MATAMOROS M., UDVARDI M., DALTON D.A. Recent insights into antioxidant defenses of legume root nodules. New Phytol. 188, 960, 2010.

19. ASHRAF M., HARRIS P.J.C. Potential biochemical indicators of salinity tolerance in plants. Plant Sci. 166, 3, 2004.

20. WANG Y., YUAN H.W., LI M., LI Y.J., MA X.J., TAN F., ZHANG J. Phenotypic and physiological responses of two willow varieties to salt stress. Isr. J. Plant Sci. 61, 73, 2013.

21. KOYAMA H., TODA T., YOKOTA S., DAWAIR Z., HARA T. Effects of aluminum and $\mathrm{pH}$ on root growth and cell viability in Arabidopsis thaliana strain Landsberg in hydroponic culture. Plant Cell Physiol. 36, 201, 1995.

22. JONES K.H., SENFT J.A. An improved method to determine cell viability by simultaneous staining with fluorescein diacetate-propidium iodide. J. Histochem. Cytochem. 33, 77, 1985.

23. WEI P., YANG Y., FANG M., WANG F., CHEN H.J. Physiological response of young seedlings from five accessions of Diospyros L. under salinity stress. Korean J. Hortic. Sci. Technol. 34, 567, 2016.
24. BRADFORD M.M. A rapid and sensitive method for the quantitation of microgram quantities of protein utilizing the principle of protein-dye binding. Anal. Biochem. 72, 248, 1976.

25. VELIKOVA V., YORDANOV I., EDREVA A. Oxidative stress and some antioxidant systems in acid rain-treated bean plants: protective role of exogenous polyamines. Plant Sci. 151, 59, 2000.

26. WANG A.G., LUO G.H. Quantitative relation relation between the reaction of hydroxylaminc and superoxidc anion radicals in plants. Plant Physiol. Commun. 26, 55, 1990.

27. KRASENSKY J., JONAK C. Drought, salt, and temperature stress-induced metabolic rearrangements and regulatory networks. J. Exp. Bot. 63, 1593, 2012.

28. HERNÁNDEZ J.A., JIMÉNEZ A., MULLINEAUX P., SEVILLA F. Tolerance of pea (Pisum sativum L.) to long-term stress is associated with induction of antioxidant defences. Plant, Cell Environ. 23, 853, 2000.

29. CHEN P., WANG H.Y., TANG X.L., BRESTIC M., SHAO H.B. Comparative physiological study between cultivated and wild soybean species under salt stress. Jökull J. 63, 114, 2013.

30. ABBASI G.H., AKHTAR J., AHMAD R., JAMIL M., ANWAR-UL-HAQ M., ALI S., IJAZ M. Potassium application mitigates salt stress differentially at different growth stages in tolerant and sensitive maize hybrids. Plant Growth Regul. 76, 111, 2015.

31. LIAO T.T., JIA R.W., SHI Y.L., JIA J.W., WANG L., CHUA H. Propidium iodide staining method for testing the cytotoxicity of 2,4,6-trichlorophenol and perfluorooctane sulfonate at low concentrations with Vero cells. J. Environ. Sci. Heal. A. 46, 1769, 2011.

32. LIAO T.T., SHI Y.L., JIA J.W., WANG L. Sensitivity of different cytotoxic responses of Vero cells exposed to organic chemical pollutants and their reliability in the biotoxicity test of trace chemical pollutants. Biomed. Environ. Sci. 23, 219, 2010.

33. KATSUHARA M. Apoptosis-like cell death in barley roots under salt stress. Plant Cell Physiol. 38, 545, 1997.

34. GARG N., SINGLA P. Naringenin-and Funneliformis mosseae-mediated alterations in redox state synchronize antioxidant network to alleviate oxidative stress in Cicer arietinum L. genotypes under salt stress. J. Plant Growth Regul. 34, 595, 2015.

35. ELLOUZI H., SGHAYAR S., ABDELLY C. $\mathrm{H}_{2} \mathrm{O}_{2}$ seed priming improves tolerance to salinity; drought and their combined effect more than mannitol in Cakile maritima when compared to Eutrema salsugineum. J. Plant Physiol. 210, 38, 2017.

36. GALLEGO S.M., PENA L.B., BARCIA R.A., AZPILICUETA C.E., IANNONE M.F., ROSALES E. P., ZAWOZNIK M.S., GROPPA M.D., BENAVIDES M.P. Unravelling cadmium toxicity and tolerance in plants: Insight into regulatory mechanisms. Environ. Exp. Bot. 83, 33, 2012.

37. HOU W., SUN A.H., YANG F.S., ZHAN Y.F., LI S.Z., ZHOU Z.D. Effects of sub-optimal temperatures and low light intensity on growth and anti-oxidant enzyme activities in watermelon (Citrullus lanatus) seedlings. J. Hortic. Sci. Biotechnol. 90, 92, 2015.

38. MONTILLET J.L., CHAMNONGPOL S., RUSTÉRUCCI C., DAT J., VAN DE COTTE B., AGNEL J.P., BATTESTIC., INZÉ D., VAN BREUSEGEM F., TRIANTAPHYLIDES C. Fatty acid hydroperoxides and $\mathrm{H}_{2} \mathrm{O}_{2}$ in the execution of 
hypersensitive cell death in tobacco leaves. Plant Physiol. 138, 1516, 2005.

39. BHASKARAN J., PANNEERSELVAM R. Accelerated reactive oxygen scavenging system and membrane integrity of two Panicum species varying in salt tolerance. Cell Biochem. Biophys. 67, 885, 2013.

40. YUREKLI F., PORGALI Z.B. The effects of excessive exposure to copper in bean plants. Acta Biol.Cracov. Bot. 48, 7, 2006.

41. KIANI-POUYA A. Changes in activities of antioxidant enzymes and photosynthetic attributes in triticale $(\times$ triticosecale wittmack) genotypes in response to longterm salt stress at two distinct growth stages. Acta Physiol. Plant, 37, 1, 2015.

42. FRIDOVICH I. Superoxide anion radical $\left(\mathrm{O}_{2}^{-}\right)$, superoxide dismutase and related matters. J. Biol. Chem. 272, 18515, 1997.

43. EKMEKÇI Y., TANYOLAÇ D., AYHAN B. Effects of cadmium on antioxidant enzyme and photosynthetic activities in leaves of two maize cultivars. J. Plant Physiol. 165, 600, 2008.
44. CHENG T.S. NaCl-induced responses in giant duckweed (Spirodela polyrhiza). J. Aquat. Plant Manage. 49, 62, 2011.

45. LEDESMA F., LOPEZ C., ORTIZ D., CHEN P.Y., KORTH K.L., ISHIBASHI T., ZENG A., ORAZALY M., FLOREZPALACIOS L. A simple greenhouse method for screening salt tolerance in soybean. Crop Sci. 27, 182, 2016.

46. KIANI S.P., GRIEU P., MAURY P., HEWEZI T., GENTZBITTEL L., SARRAFI A. Genetic variability for physiological traits under drought conditions and differential expression of water stress-associated genes in sunflower (Helianthus annuus L.). Theor. App. Genet. 114, 193, 2007.

47. CHAVES M.M., FLEXAS J., PINHEIRO C. Photosynthesis under drought and salt stress: regulation mechanisms from whole plant to cell. Ann. Bot. 103, 551, 2009.

48. BUCHANAN B.B., GRUISSEM W., JONES R.L. Biochemistry and Molecular Biology of Plants. American Society of plant physiologists, Rockville. 2000. 